Japan. J. Med. Sci. Biol., 21, 427-430, 1968

\title{
LATENT INFECTION OF TOXOPLASMA IN SWINE EYES AND DIAPHRAGM
}

The latent infection of Toxoplasma in the muscle of humans, dogs, and cats not associated with the pathological changes was found by the authors previously (Katsube et al., 1967). In swine, there are no data on the latent infection without lesions, except one reported by Abe et al. (1967), while much attention has been given to another type of latent infection characterized by swelling of the gastric and hepatic lymph nodes with hyperaemia or hemorrhage, focal necrosis in the liver, and petechial hemorrhage in the lung, with or without other changes (Hirayama et al., 1962; Kanai et al., 1963; Koshimizu et al., 1963; Kaneko et al., 1967). The latent infection in the tissue of the eyes has never been clearly demonstrated in any host species. Therefore, this investigation was performed on the specimens of eyes and diaphragm derived from apparently healthy swine at ante- and post-mortem examinations in order to obtain further epidemiological information. It was attempted in this work also to know the reliability of the serological tests for detecting the latent infection in swine, but this will be reported later with results in other host species.

The diaphragm, liquid of vitreous body, and chorioretinal coat from eight slaughtered swine and the diaphragm from other thirty-seven animals were obtained for isolation of Toxoplasma. The swine were slaughtered at the Yokohama Slaughter House, and they showed no symptoms or lesions at either ante- or post-mortem examination. Twenty grams of the diaphragm was digested with $200 \mathrm{ml}$ of a $0.25 \%$ trypsin solution in a manner reported previously (Katsube et al., 1967). From the vitreous body of the eyes of a swine, usually 1 to $1.5 \mathrm{ml}$ of liquid was obtained. To the liquid, saline containing penicillin $(100 \mathrm{U} / \mathrm{ml})$ and streptomycin $(100 \mu \mathrm{g} / \mathrm{ml})$ was added to make $5 \mathrm{ml}$. A half part of the chorioretinal coat of the two eyes of each individual was emulsified with $5 \mathrm{ml}$ of saline by a glass mill. The remaining part of the coat of the eyes was subjected to pathological examinations. Each specimen was inoculated into the peritoneal cavity of a group of 5 mice (the gpc strain, 4 5-week-old). The mice received intramuscular administration with cortisone acetate $(5 \mathrm{mg} / \mathrm{mouse})$ at the same time. Afterwards, the inoculated mice were examined in exactly the same way as that reported previously (Katsube et al., 1967). The stamp smears of the gastric lymph node of the swine were examined microscopically with the fluorescent antibody method for the presence of Toxoplasma. Some sections from the brain, liver, lung, spleen, kidney and chorioretinal coat fixed by $10 \%$ formalin were stained by hematoxilin-eosin and others by PAS. When Toxoplasma were detected, the sections were also stained with fluorescent antibody.

Toxoplasma were isolated from a total of 5 (11.1\%) of the 45 slaughtered swine (Table). Three of 37 swine of which the diaphragm only was examined, and 2 of 8 swine examined with the diaphragm and eyes were found to have been infected. In the latter 2 cases, one showed Toxoplasma in the diaphragm, liquid of vitreous body, and chorioretinal coat, and the other had the organisms in the chorioretinal coat only. No Toxoplasma were shown in the stamp smears of the gastric lymph nodes from the 45 swine by direct microscopic examination. Histopathological ex- 
Table. Results of isolation of Toxoplasma from slaughtered swine

\begin{tabular}{|c|c|c|c|c|c|c|c|}
\hline \multirow{2}{*}{$\begin{array}{c}\text { Group } \\
\text { No. }\end{array}$} & \multirow{2}{*}{$\begin{array}{l}\text { Specimens } \\
\text { for } \\
\text { isolation }\end{array}$} & \multirow{2}{*}{$\begin{array}{l}\text { Number } \\
\text { of } \\
\text { animals } \\
\text { examined }\end{array}$} & \multirow{2}{*}{$\begin{array}{l}\text { Number of } \\
\text { cases posi- } \\
\text { tive for } \\
\text { isolation }\end{array}$} & \multicolumn{4}{|c|}{ Isolation of the organisms from } \\
\hline & & & & $\begin{array}{c}\text { Swine } \\
\text { No. }\end{array}$ & Diaphragm & $\begin{array}{l}\text { Liquid of } \\
\text { vitreous } \\
\text { body }\end{array}$ & $\begin{array}{l}\text { Chorio- } \\
\text { retinal } \\
\text { coat }\end{array}$ \\
\hline \multirow{3}{*}{$\mathrm{I}$} & \multirow{3}{*}{ Diaphragm } & \multirow{3}{*}{37} & \multirow{3}{*}{3} & No. 3 & + & - & - \\
\hline & & & & $\{$ No. 31 & + & - & - \\
\hline & & & & (No. 39 & + & - & • \\
\hline \multirow{2}{*}{ II } & \multirow{2}{*}{$\begin{array}{l}\text { Diaphragm } \\
\text { and } \\
\text { eyes }\end{array}$} & \multirow{2}{*}{8} & \multirow[b]{2}{*}{2} & No. 1 & - & - & + \\
\hline & & & & $\left\{\begin{array}{l}\text { No. } 2 \\
\text { ( }\end{array}\right.$ & + & + & + \\
\hline Total & & 45 & $5(11.1 \%)$ & & $4 / 45^{*}$ & $1 / 8$ & $2 / 8$ \\
\hline
\end{tabular}

* Number of cases positive for Toxoplasma/Number of cases examined

- Not examined

aminations neither ascribed the lesions to toxoplasma infection nor demonstrated the organisms in the tissues. As for the virulence of the strains isolated, 2 strains from swine Nos. 1 and 31 were weakly virulent to mice, forming cysts in the brain, even after serial passages. Another strain from the diaphragm of swine No. 2 was more virulent to mice killing them between 1 and 2 weeks. The other 4 strains formed cysts in the brain of mice at the 1st passage, and increased in pathogenicity to mice by subsequent passages becoming able to kill them within 2 weeks.

Thus, the presence of latent infection of Toxoplasma in swine without pathological changes in their gastric lymph node, liver, lung, and other organs was confirmed in this investigation. A similar survey performed by Abe et al. (1967) also showed latent infection without lesions in 2 of 100 swine slaughtered at the Shibaura Slaughter House. Ishii et al. (1962) isolated the organisms from the diaphragm of $3(4.9 \%)$ of 61 healthy swine slaughtered at a slaughter house, though no examination was made on the lymph node and other organs. Then it may safely be said that 2 to $10 \%$ of apparently healthy swine are infected with Toxoplasma in their muscles. As for the incidence of the latent infection with lesions in slaughtered swine, Hirayama et al. (1962) found in $82(0.13 \%)$ of 58,940 swine slaughtered in the Tokyo area and Kaneko et al. (1967) in $95(0.079 \%)$ of 119,721 animals slaughtered at the Omiya Slaughter House in Saitama. From the viewpoint of public health, the latent infection in swine without any pathological changes is of much importance, because the latent infection could not be detected at meat inspection and the incidence is higher than that associated with lesions. Our present interest is to learn whether these two forms of infection in swine represent two different stages in the same course or whether these forms and the clinical form represent independent courses. The relationship among them remains unknown. Another interesting finding which called our attention was the confirmation of the presence of latent infection in the swine eyes. In swine and chicken toxoplasmosis, the organisms were detected in the specimens from their eyes (Biering-S $\phi$ rensen, 1956 ; Morinaga et al., 1966). Meyer (1963) isolated the organisms frequently from the retina of cattle in Argentina. In humans, granulomatous uveitis or focal chorioretinitis were regarded as one of the 
major symptoms of toxoplasmosis from the serological results in the patients who developed the symptoms(Woods et al., 1954; Oniki, 1967; Tsunematsu and Kamei, 1968). Ikui(1954), Sato(1959), and Matsubayashi and Muto(1960) isolated the organisms from cerebrospinal fluid of patients with focal chorioretinitis and considered the inflammation to have been caused by toxoplasma infection. In experimental ocular toxoplasmosis in rabbits and guinea-pigs produced by direct inoculation into their eyes, the organisms developed various types of inflammation in the eyes (Hogan, Zweigart, and Lewis, 1956 ; Kurisaki and Kimura, 1958a, b ; Matsutani, 1960) Dubey(1967) isolated the organisms from an emulsion of the eyes of a case of experimental feline toxoplasmosis produced by oral administration of the infected mouse brain. Reviewing these results, the authors consider that the ocular tissues should serve as sites at which Toxoplasma are parasitizable in a form of latent infection, and especially the chorioretinal coat may serve as an important one.

\section{REFERENCES}

Abe, H., Takaku, H., Fukazawa, T., Iwamoto, G., Watanabe, K., Suzuki, T., Miki, H. AND ITO, M. (1967) : Isolation of Toxoplasma from swine carcases. Proc. 63rd Meeting of Japan. Soc. Vet. Sci.

BIERING-S $\phi$ RENESEN, U. (1956) : Poultry toxoplasmosis. On the occurence of endemic toxoplasmosis (toxoplasmosis gallinarum) in Danish chicken flocks. Nord. Veterinaermed., 8, 140-164.

Dubey, J. P. (1967): Distribution of Toxoplasma gondii in the tissues of infected cats. 1. Isolation in mice. Trop. Geogr. Med., 19, 199-205.

Hirayama, T., Uchihara, T., Nakamura, T., Tanaka, J., Kitaura, Y., Matsui, T., SAto, H., SAEKI, Y. AND OCHI, Y. (1962): Swine toxoplasmosis detected at meat inspection in Tokyo area. J. Japan Vet. Med. Ass., 15, 71-74. (text in Japanese)

Hogan, M. J., ZWeigart, P. A. AND Lewis, A. (1956): Persistence of Toxoplasma gondii in ocular tissues. 1. J. Parasitol., 42 (part II), 84-88.

IkUi, H., Nonaka, M., Miyazaki, I. AND Yamamoto, I. (1959): Ocular toxoplasmosis in adult. Report of a case of central exudative retinitis caused by Toxoplasma. J. Clin. Ophthal. (Tokyo), 13, 1485-1491. (text in Japanese)

Ishi, T., Kobayashi, A. Koyama, T., Kumada, M., Komiya, Y., Fukazawa, T., Saito, M. AND Koshimizu, K. (1962): Studies on Toxoplasma. 4. A survey of pork meat for the presence of Toxoplasma. Japan. J. Parasitol., 11, 184-191.

Kanai, T., Fukazawa, T., Koshimizu, K., Harada, Y., Nakamura, T., Saito, K., Sugaya, S. AND ToKutomi, G. (1963): Swine toxoplasmosis encountered in a slaughter house. J. Japan Vet. Med. Ass., 16, 348-352. (text in Japanese)

Kaneko, N., Kosuge, G., Iwasaki, H., Suzuki, M., Tomioka, H., Naito, H., Kinoshita, O. AND ITO, R. (1967): Relationship between post-mortem findings of toxoplasmosis and protozoal detection observed in meat inspection. J. Japan Vet. Med. Ass., 20, 151-154. (text in Japanese)

Katsube, Y., Hagiwara, T., Ueda, K., Miyakawa, H., Imaizumi, K., Hanaki, T. and NoBUTO, K. (1967) : Studies on toxoplasmosis. 1. Isolation of Toxoplasma from muscle of humans, dogs, and cats. Japan. J. Med. Sci. Biol., 20, 413-419.

Koshimizu, K., Fukazawa, T., Kanai, T., Harada, Y., Nakamura, T., Saito, K., SugaYa, S., TOKUTOMI, G. AND AKAO, Y. (1963): Distribution of toxoplasma antibodies in slaughtered hogs and workers of a Tokyo abattoirs. J. Japan Vet. Med. Ass., 16, 460-464. (text in Japanese)

KURISAKI, M. AND KIMURA, R. (1958a): Experimental studies on ocular toxoplasmosis Report 1. Acta Societatis Ophthalmologicae Japonicae, 62, 2394-2398. (text in Japanese) 
IDEM (1958b) : Experimental studies of ocular toxoplasmosis. Report 2. Folia Ophthalmologica Japonica, 9, 601-604. (text in Japanese)

MAtsubayashi, M. AND Muto, K. (1960) : A case of congenital toxoplasmosis. Japanische Monatschrift für praktische Augenheilkunde, 54, 80. (text in Japanese)

MatsutANI, Y. (1960) : Experimental studies on ocular toxoplasmosis. Acta Societatis Ophthalmologicae Japonicae, 64, 1834-1848. (text in Japanese)

MeYer, H. F. (1963): Isolation of Toxoplasma gondii from retina of cattle. Rev. Med. Vet., B. Aires, 44, 423-430. Cited in Vet. Bull. (1964) 34, 721-722.

Morinaga, S., Mochida, M., Kudo, Y., Matsuo, H. ANd Tsubota, R. (1966) : Detection of Toxoplasma in aqueous humour derived from swine toxoplasmosis by fluorescent antibody technique. Proc. 88th Meeting of Ass. Japan. Publ. Health Vet.

ONIKI, S. (1967): Significance of retinochoroiditis in diagnosis of toxoplasmosis. Proc. 36th Meeting of Japan. Soc. Parasitol.

SATo, T., URATA, S. AND TsunOdA, Y. (1959): A case of toxoplasmosis. Japanische Monatschrift für praktische Augenheilkunde, 53, 1075. (text in Japanese)

Tsunematsu, Y. AND KAMEI, K. (1968): Prevalence of toxoplasma antibodies in various disease. Proc. 37th Meeting of Japan. Soc. Parasitol.

Woods, A. C., JacoBs, L., Wood, R. M. AND CoOK, M. K. (1954) : A study of the role of toxoplasmosis in adult chorioretinitis. Amer. J. Opthalmology, 37, 163-177.

Department of Veterinary Science,

National Institute of

Health, Tokyo 141, Japan

Yokohama Meat Inspection

Laboratory, Yokohama 230, Japan

Received: November 30th, 1968

\author{
YASUJI KATSUBE \\ TOSHIKATSU HAGIWARA \\ HIROSHI MIYAKAWA \\ TAKESHI MUTO \\ KIYOSHI IMAIZUMI
}

KEIZO MASUDA

$\mathrm{l}_{\text {WAO MIYAKE }}$

勝部泰次・萩原敏且・宮川博・武藤健・今泉清（国立予防衛生研究所獣疫部）

増田敬三・三宅膂（横浜市食肉衛生検查所） 